UDK 351.712.2.043:614.8

Original scientific paper

\title{
PARTNERSHIPS IN MODERN PROCUREMENT SYSTEMS AS THE BASIS FOR COMPANIES' STABILITY AND GROWTH IN CRISIS AND UNPREDICTABLE CIRCUMSTANCES
}

\author{
Matej Galić, PhD, Research Associate \\ The University of Applied Sciences Baltazar \\ Vladimira Novaka 23, Zaprešić, Croatia \\ mgalic@bak.hr
}

\author{
Ivan Ružić, PhD, Senior Research Associate \\ The University of Applied Sciences Baltazar \\ Vladimira Novaka 23, Zaprešić, Croatia \\ iruzic@bak.hr
}

\section{Tomislav Horvat, MSc in Economics}

Belje plus d.o.o.

Sv. Ivana Krstitelja 1a, 31326 Darda, Croatia

tomislav.horvat@belje.hr

\section{ABSTRACT}

All functions within the company, regardless of its size and activity, meet with an extremely dynamic economy and an environment in which they perform many day-to-day activities. In that sense, procurement is no different. It no longer serves only the purpose of ordering goods or services at the request of production at the lowest possible prices. Today's modern procurement systems offer solutions, improvements and thoughts on all aspects of business operations in which they are involved. There is a special emphasis on the dynamic resolution of challenging situations, which lies in unpredictable circumstances and crisis. The procurement department always works closely with other functions that directly affect production, and this is where extremely dynamic, high-quality and timely communication is expected. Communication with functions within the company is followed by communication with partners, where procurement becomes a sort of link between production and suppliers.

Members of the procurement team are in most cases representatives of their companies, and it is based on their communication skills, behaviour and decisions that the image of the company is created among partners. Quality and timely communication of procurement team members 
with partners can play a key role for the continuation of production in turbulent market situations. Managers must organize all procurement processes in a quality manner, as well as motivate, educate and reward members of the procurement department. With their comments, opinions, advice and experience, partners offer an additional perspective, solution and an alternative path in the further planning of steps which would help achieve all of company's objectives. Experienced management, especially in times of crisis, use all possible information to make quality decisions, but also learn from these situations in order to make all possible preparations in regular business operations to minimize the shock that a new crisis could cause.

The theoretical part of the paper will present a description of the concept of procurement business, management and crisis management, business and crisis communication, creating partnerships, and maintaining the company's image. The empirical research, conducted through questionnaires which were filled in by employees from the procurement department in the Republic of Croatia, provides us with answers about the importance of partnerships, with a special emphasis on the current coronavirus pandemic. In conclusion, we have explained proposals for improving and maintaining partnerships in the procurement business during crisis, as well as in regular business situations.

Keywords: communication, crisis management, modern business, partnership, procurement.

\section{INTRODUCTION}

Purchasing business in times of crisis and unpredictability shows its exceptional importance for any company, regardless of its size, activity or market orientation. In such conditions, procurement is by no means exclusively responsible only for negotiations with the suppliers, i.e., the procurement of required goods and services. From the procurement employees are required to have highly developed emotional intelligence and problem-solving mindset. Crisis situations usually come quickly and suddenly, and the procurement becomes a function in charge of solving challenges and obtaining solutions to the current problem. At no time should the business, production or performance of services be stopped or slowed down, especially in times of crisis, and this is a great burden that is born by every employee in the purchasing business. This paper is divided into a theoretical part that includes previous research done through scientific papers and a review of conclusions on crisis management from the expert literature. It is difficult to come to a conclusion without detailed research on how employees of the procurement business react to times of crisis, and it is difficult to confirm with certainty what factors have most affected and hindered business activities. Consequently, with the use of a questionnaire, the procurement employees were investigated that were based on the territory of the Republic of Croatia. In advance were set the hypotheses that were the basis for writing of the entire paper, and especially for the conducted research, and those are: 
H1. Investing time in the activity of creating and maintaining partnerships is crucial during unpredictable crisis situations on the market.

$\mathrm{H} 2$. To the procurement employees, during the crisis situations are more important delivery dates, quality cooperation and supplier assistance when finding alternative solutions, than the lowest price and payment terms.

H3. Awareness of the importance of education about internal training on crisis management and the importance of team building activities is highly present among procurement staff.

\section{PREVIOUS RESEARCH}

Filipović, Krišto and Podrug conducted an empirical survey with questionnaires during the period from June 2016 to January 2017, and they included large companies in the Republic of Croatia therefore 106 companies participated in the survey. It was concluded that the correlation between external crisis situations and business continuity management development is positive and of medium strength, meaning that the increase in the risk of a crisis situation will increase the degree of development of business continuity management. Prediction of crisis situations is the initial step in business continuity management planning. Active enterprises predict and prevent the crisis situations, while, in passive ones, the establishment of business continuity management model is mediated by the intensity of recurrence of crisis situation. ${ }^{1}$

Mikušová and Horváthová have investigated the reactions of small business managers to crisis management in the Czech Republic. The survey was conducted during 2009, 2011 and 2016. Research dated from 2011 and 2016 were conducted to show changes and conclusions compared to the 2009 results. A total of between 925 and 1026 respondents participated in the surveys each year. The main conclusion is that small business managers simply did not know how they can and should prepare for crisis, and another reason is the cost of additional preparations during the times of a crisis due to the lack of financial experts. The answers varied with age, but it can be drawn the same conclusions. The authors believe that little time has passed since the 1990s, when the Czech Republic switched from a planned economy to an open market and thence managers had too little time and

Filipović, D.; Krišto, M.; Podrug, N., Impact of crisis situations on development of business continuity management in Croatia, Management: Journal of Contemporary Management Issues, Vol. 23 No. 1, 2018, pp. 99-122. 
opportunities to gain experience related to crisis periods. ${ }^{2}$ The need to manage uncertainties indicates that quality risk management is the best crisis management and that primary a culture of crisis management is an understanding of management as a process leading to crisis avoidance. ${ }^{3}$

It turned out that crisis management is always connected with the planning process, so it can be a planning process before the crisis (preparation for crisis times), during the crisis (how to eliminate the crisis) and after the crisis (planning responses to future, similar crises). Operational and strategic management must be linked together in planning and executing planned tasks, and no level of management can function separately.

The basic function of any crisis plan is to define procedures and human and material resources and also to inform and guide participants towards the execution of the plan. ${ }^{4}$ When any of the crisis breaks out, the most important thing is to face the consequences and establish crisis communication. Such communication must be with both the external and internal public, i.e., with all publics involved in the crisis. $^{5}$

Planning is associated with the concept of communication, especially communication that is professional, timely, tangible and fast. Regular meetings on crisis communication bring many steps for the improvement of the crisis planning and process execution, cohesion within teams is developed, solutions are discovered and without difficulty is coming up with the new proposals to address any of the challenging situations.

Crisis managers have a duty to timely and accurately inform employees about the nature of problems, internal and external causes of business crisis, how to overcome and manage the business crisis, all with the aim of limiting opportunities for resistance, misunderstandings and unnecessary speculation. ${ }^{6}$

2 Mikušová, M.; Horváthová, P., Prepared for a crisis? Basic elements of crisis management in an Organisation, Economic research - Ekonomska istraživanja, Vol. 32 No. 1, 2019, pp. 1844-1868.

3 Funda, D., Doprinos međunarodnih norma u rješavanju poslovnih kriza, Visoka škola za poslovanje i upravljanje s pravom javnosti «Baltazar Adam Krčelić» Zaprešić, Hrvatska, Tranzicija, Vol. 13 No. 27, 2011, pp. 98-109.

$4 \quad$ Lujanac, D.; Mihalinčić, M.; Markotić, I.; Kožul, I., Krizni menadžment zdravstva, Journal of Applied Health Sciences = Časopis za primijenjene zdravstvene znanosti, Vol. 4 No. 1, 2018, pp. 115-120.

5 Tomić, Z.; Sapunar, J., Krizno komuniciranje, časopis Filozofskog fakulteta Sveučilišta u Mostaru, No. 1, 2006, pp. 298-310.

6 Brčić, R.; Malbašić, I.; Đukes, S., Uloga i ponašanje zaposlenika u kriznom menadžmentu, Ekonomski pregled, Vol. 64 No. 3, 2013, pp. 279-296. 
Never in history has it been possible to predict the exact beginning of a particular crisis, its intensity, duration and methods of behaviour of the company to successfully survive the crisis. Previous crises can be great for analysing and structuring processes to deal more successfully with the future crises. All employees should observe the market closely and look for early signs of future crisis periods. This is exactly one great preventative method.

Structured business process management provides real early indicators of crisis that appear well before the numerical values are expressed in financial business reports (which are today considered as early indicators of crisis) and to give space for managers to take the necessary actions in time. ${ }^{7}$

\section{THE IMPORTANCE OF PARTNERSHIPS IN CRISIS COMMUNICATION}

Partnerships for any business entity are exclusively a positive factor for successful and efficient doing business, regardless of activity, size and market orientation. Crisis situations especially show the importance of mutually regulated partnerships, regardless of whether they were legally regulated partnerships or informal partnerships based on daily business. Representatives of the company with their behaviour, attitudes, manner of communication, degree of professionalism create a certain image of the company in public, which can attract potential partners or make them restrained in terms of cooperation with the observed company.

One of the basic needs of every businessman or individual in prominent social functions can separate the need to project of a favourable image into different target groups. By this we understood associates, superiors, business partners, customers. ${ }^{8}$ The development of technology, especially the use of numerous electronic messaging systems has affected on the volume and dynamics of business meetings. Work in practice shows that a quality meeting between partners can remove many doubts in a short period of time, an agreement can be reached on future strategic projects and to create additional connections between partners. Partnerships are also created through informal communication, where purchasing and sales share their personal experiences and where employees connect on a professional and personal level.

Kruljac, Ž.; Knežević, D., Prevencija ili evidencija: prepoznati rane simptome krize ili evidentirati gubitke u poslovanju?, Obrazovanje za poduzetništvo - E4E : znanstveno stručni časopis o obrazovanju za poduzetništvo, Vol. 10 No. 2, 2020, pp. 155-168.

$8 \quad$ Leinert-Novosel, S., Komunikacijski kompas, Plejada, Zagreb, 2012, p. 58. 
Good meetings will bring together people with similar expectations, whose compliance can have a positive impact on most group members. It will create influence and will attract other individuals who will incline as on the same, like-minded people and people of the same tendencies for the development of the group and the whole company'. Professional public purchasers and private organizations must take note of how collaborative their contracting practices are and how they may influence partnering so that they can create strong basis for further partnering during procurement implementation. ${ }^{10}$ Complaints should be approached like with any other negotiating situation in which there is a certain conflict of interest, so we shall prepare well and in accordance with the win-win philosophy try to remove sources of customer concern and offer solutions that are in the best interest of the both stakeholders ${ }^{11}$.

Many managers share the opinion that the crisis cannot happen to them. They are too convinced of their own power, so they do not think about the possible dangers, and even less about the preparation of a crisis plan. ${ }^{12}$ False self-confidence in oness own knowledge and abilities without experience and regular market research can be disastrous during the first and most severe blows of a new crisis. Employees without management cannot make important and strategic decisions; there, management seek for calmness, knowledge and creativity that are required through making important decisions, quick adjustment of business processes and creation of alternatives. In a crisis, management must work with partners and with all other entities that directly and indirectly affect the company.

The challenge, however, lies in developing a management philosophy or corporate culture in which independent and autonomous trading parties can relinquish some sovereignty and control, while also engaging in planning and organizing which takes into account the needs of the other party. ${ }^{13}$ By means of direct strikes, company management can improve the creation or further development of partnerships between its own employees and longstanding or future partners. A simple step is to invest in your employees, especially in the area of developing commu-

9 Petar, S., Sastankom do cilja : vještina vođenja uspješnih sastanaka, Školska knjiga, Zagreb, 2013, p. 54.

10 Keränen, O., Dynamics of the transition process towards partnership thinking in centralized public procurement, Industrial Marketing Management, Vol. 65, 2017, p. 86-99.

11 Tomašević Lišanin, M., Profesionalna prodaja i pregovaranje, Hrvatska udruga profesionalaca u prodaji, Zagreb, 2010, p. 298.

12 Novak, B., Krizno komuniciranje i upravljanje opasnostima : priručnik za krizne odnose sjavnošcu, Binoza press Zagreb, 2001, p. 132.

13 Mohr, J.; Spekman, R., Characteristics of partnership success: partnership attributes, communication behavior, and conflict resolution techniques, Strategic management journal, Vol. 15, No. 2, 1994, p. 135152. 
nication and presentation skills. An important item of education is conflict management and education that is related to people's personality types. In particular, this conclusion applies to new, young employees without previous experience in negotiations. Those employees with longer work service and numerous meetings held may have gained experience, but this may not be the rule.

Mastering communication in order to improve business performance, especially in management and trade, where communication with associates and customer relations means business success or failure, is one of the priorities of every businessman. ${ }^{14}$ Dealing with difficult people is the most demanding. They have fierce feelings or are hostile to others, so the other side often loses confidence. This is a challenge even for the most skilled negotiators, due to negative, disarming and manipulative behaviour. ${ }^{15}$ The problem of communication during and after the crisis is that no two crises are the same. Some incidents require an immediate and aggressive communication with important stakeholders - consumers, customers, clients, government officials, the judiciary - and if this has not been done, the crisis may deepen and turn into a real disaster for the organization. ${ }^{16}$ The right culture in both the customer and supplier organizations must exist to facilitate and encourage joint problem solving and decisionmaking across internal functions. ${ }^{17}$ Face-to-face communication mediates the relationship between intra-organizational task interdependence and cognitive congruence. ${ }^{18}$

Communicating and creating partnerships in normal market conditions is challenging, but additional pressure on procurement staff creates communication in the conditions of crisis situations. Procurement is never a separate function, but communicates dynamically with all employees within the company, specifically with the production, marketing and finance departments. Procurement employees collect communication inputs from other functions, requests, compliments, complaints or negative reactions and have the task of shaping the correct communication messages towards partner. In times of crisis, procurement staff have the task of mitigating all the negative messages due to possible non-delivery of goods,

${ }_{14}$ Vodopija, Š., Opća i poslovna komunikacija : priručnik i savjetnik za uspješnu komunikaciju, Naklada Žagar, Rijeka, 2006, p. 53.

15 Biondić Vince, D., Kako uspješno pregovarati i povećati svoju vrijednost, napredovati, te zaraditi više!, vodič za vrhunske pregovarače, Biondi, Zagreb, 2012, p. 63.

16 Tafra-Vlahović, M., Upravljanje krizom : procjene, planovi, komunikacija, Visoka škola za poslovanje i upravljanje s pravom javnosti "Baltazar Adam Krčelić”, Zaprešić, 2011, p. 193.

17 McIvor, R.; McHugh, M., Partnership sourcing: an organization change management perspective, Journal of Supply Chain Management, Vol. 36, No. 2, 2000, p. 12-20.

18 Grawe, S.J.; Ralston, P.M., Intra-organizational communication, understanding, and process diffusion in logistics service providers, International Journal of Physical Distribution \& Logistics Management, Vol. 6, 2019, pp. 662-678. 
delays in deliveries or deviations in quality. Here, the experience and development of emotional intelligence is crucial.

Crisis communication can be defined as a dialogue between an organization and its public immediately before, during and after a negative event. ${ }^{19}$ Destructive negotiations are processes in which one or both parties try to win even when there is a danger of losing while formally one of the parties' may have won. ${ }^{20}$ The factors that best model strategic performance are different from those that best model operational performance. Having joint partnership management and relation-specific assets goes hand-in-hand with enhancing the company's competitive position, and is therefore of strategic importance to the partners. ${ }^{21}$ It can be concluded that destructive negotiations cannot bring good results to either side in the long run and it can occur as the illusion of victory to one or the other negotiating party. If no agreement can be reached, scheduling a new meeting at another time may yield better results than to accept destructive conclusions from one of the meetings.

\section{RESEARCH METHODOLOGY AND ITS LIMITATIONS}

The specificity of the topic of the paper required a targeted survey of procurement employees, while the survey questionnaire was developed through the Google forms platform. The authors sent surveys to procurement employees they know personally, and others were contacted via social media. In the survey were participated the procurement employees from the territory of the Republic of Croatia. A total of 48 procurement staff responded. After the survey and data collection, data processing was performed. Basic statistical parameters were calculated and descriptive data (frequencies, percentages, arithmetic means and standard deviations) were presented. The obtained results are presented in tables and graphs. Statistical processing of the collected data was performed using the statistical program IBM SPSS Statistics 20. The aim of the study was to make known the opinions of procurement staff in the Republic of Croatia related to procurement operations during the COVID-19 pandemic in 2020, which were the biggest challenges, and on which way the procurement business and operations of the company in general can prepare for future periods of crisis.

It was difficult to find the same number of employees in the procurement business from different sectors of the economy; to find the same number of employees

\footnotetext{
19 Jugo, D., Menadžment kriznog komuniciranja, Školska knjiga, Zagreb, 2017, p. 29.

20 Rouse, M. et al., Poslovne komunikacije : kulturološki i strateški pristup, Zagreb, 2005, p. 194.

21 Sodhi, M. S.; Son, B. G., Supply-chain partnership performance, Transportation Research Part E: Logistics and Transportation Review, Vol. 45, No. 6, 2009, p. 937-945.
} 
according to different age groups and length of service. A conclusion could not be reached by a direct comparison of procurement employees by their activity, age and length of service, which would be otherwise an extremely interesting contribution to the research of procurement operations. Previous procurement business researches have not focused insofar on targeted survey of procurement employees, - especially was absent the lack of research related to crisis procurement management. In Table 1 is shown the structure of employees and the total number of respondents who responded to the survey questionnaire.

Table 1. Sample structure $(N=48)$

\begin{tabular}{|l|l|l|l|}
\hline \multirow{3}{*}{ Gender } & & N & Percentage \\
\hline \multirow{4}{*}{ Age } & Male & 27 & $56.3 \%$ \\
\cline { 2 - 4 } & Female & 21 & $43.7 \%$ \\
\hline \multirow{4}{*}{ Length of service } & $25-34$ & 15 & $31.3 \%$ \\
\cline { 2 - 4 } & $35-44$ & 23 & $47.9 \%$ \\
\cline { 2 - 4 } & $45-54$ & 10 & $20.8 \%$ \\
\hline \multirow{5}{*}{ Education } & $0-10$ years & 15 & $31.3 \%$ \\
\cline { 2 - 4 } & $11-20$ years & 26 & $54.2 \%$ \\
\cline { 2 - 4 } & $21-40$ and higher & 7 & $14.5 \%$ \\
\cline { 2 - 4 } & Elementary School & 1 & $2.1 \%$ \\
\cline { 2 - 4 } & Secondary education (SSS) & 5 & $10.4 \%$ \\
\cline { 2 - 4 } & Higher education / professional study & 8 & $16.7 \%$ \\
\cline { 2 - 4 } & University degree / university study & 31 & $64.6 \%$ \\
\cline { 2 - 4 } & MSc / PhD & 3 & $6.2 \%$ \\
\hline
\end{tabular}

Source: authors.

The research was conducted on the sample of 48 employees employed in the procurement sector of various companies (56.3\% of male and $43.7 \%$ of female) aged 25 to 54 years. Most of those employees have 11 to 20 years of work experience $(54.2 \%)$ and have a university degree (graduated, 64.6\%). Attempts were made to reach procurement employees who are about to retire (55-65 years old), however it was exceptionally hard to find employees of that age through direct contacts or through social networks. On the other hand, there were no respondents younger than 25 years of age. It is possible that most procurement jobs require a completed academic degree (bacc. Oec or titles from other social sciences) and it is more difficult for younger people to get the opportunity to work in procurement before they reach 25 years of age. On Figure 1 is shown the total number of respondents who responded to the survey questionnaire given the size of the company. 


\section{RESULTS AND DISCUSSION}

Most of the employees who participated in the survey, work in companies with total of 51 and 250 employees and the companies with the more than $251 \mathrm{em}$ ployees (a total of $72.9 \%$ ). The goal was to examine an equal number of employees from all sizes of companies in order to draw better conclusions. More potential respondents were found from companies with a minimum of 51 employees. It would be interesting to compare the results of an equal number of surveyed procurement employees from micro and large enterprises. As a rule, the procurement function is more developed as there are more employees within the procurement team in larger companies due to the complexity of the procurement business.

Figure 1. The size of the enterprise

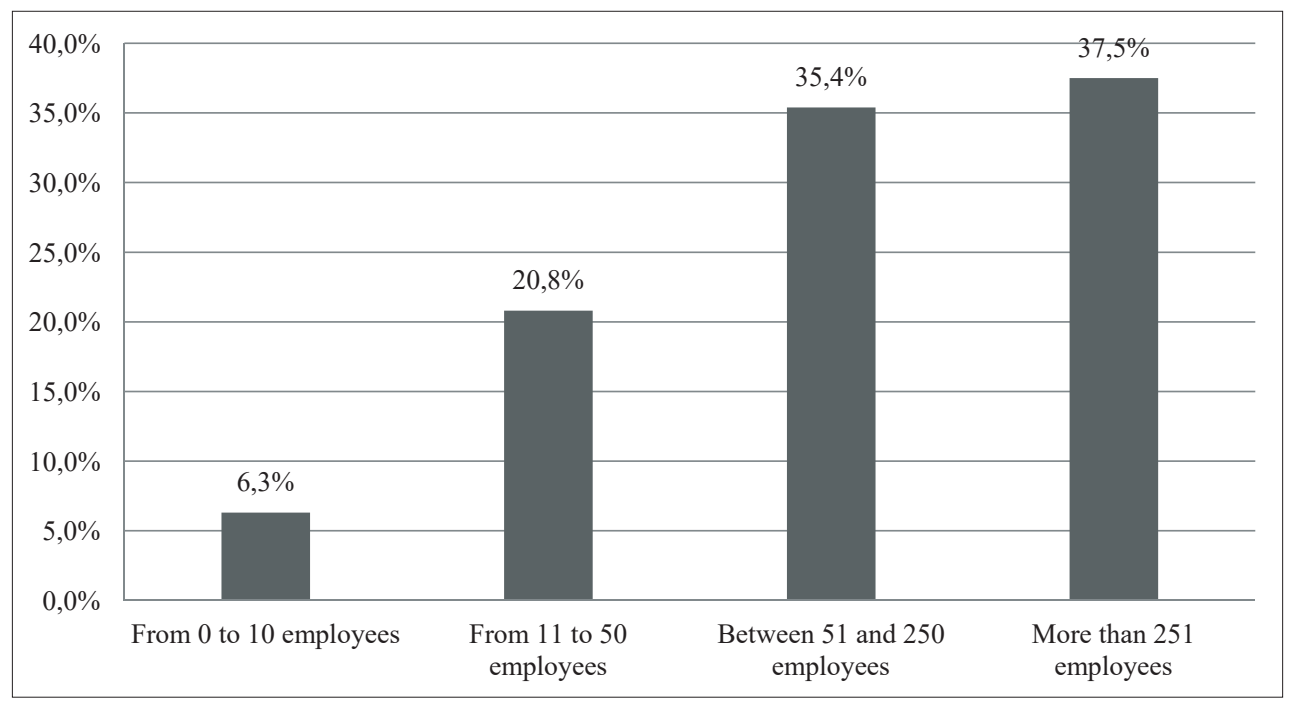

Source: authors.

The distribution of procurement employees who responded to the survey questionnaire according to the activity of the company they come from is shown in Figure 2. 
Figure 2. Company activity

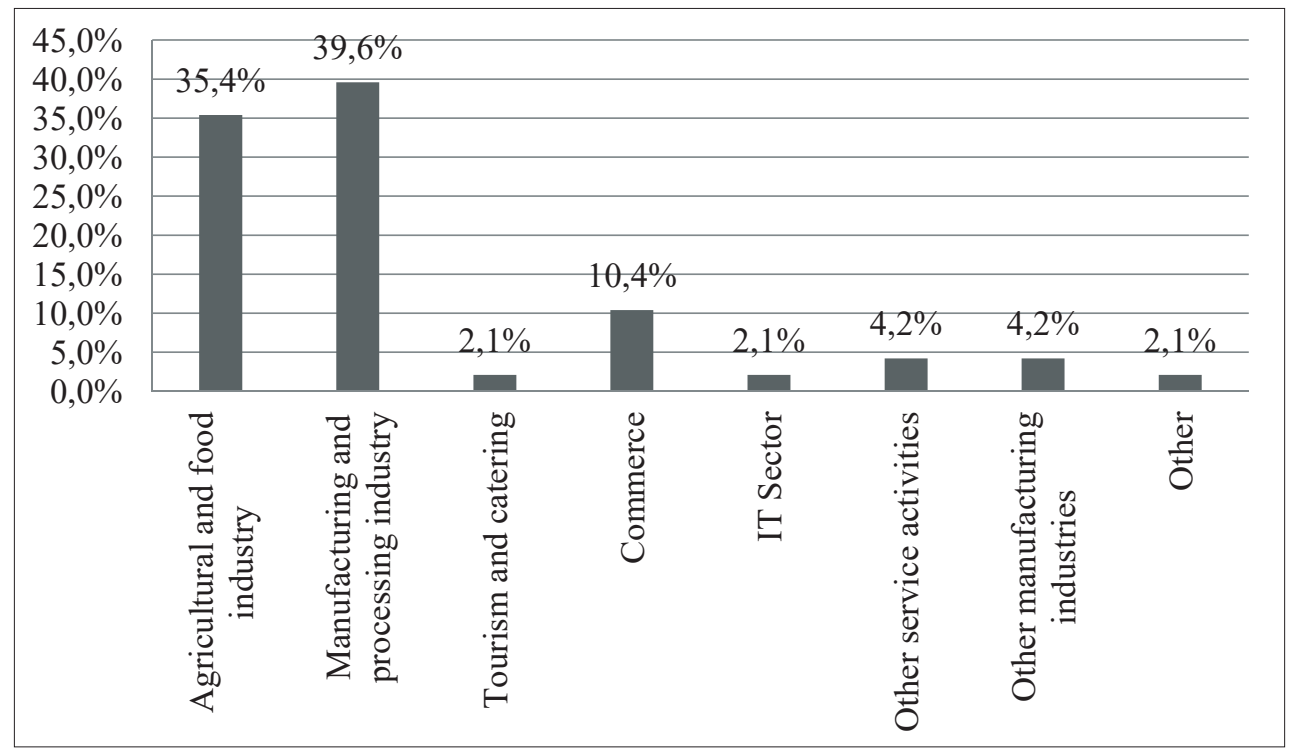

Source: authors.

If we look at the results based on the activities of the company, most of the employees work in the production and processing (39.6\%) and agricultural and food industries (35.4\%). As stated in the research methodology, employees were targeted through personal contacts and social networks. The agricultural activity and the manufacturing and processing industry in general are the two most represented industries according to the structure of the respondents. The procurement function in these industries is extremely developed due to the complex business and the importance of procurement, especially in dynamic, crisis situations. IT companies, tourism and catering and similar service activities often do not have a developed procurement function, but the responsible person in addition with other obligations performs the function of ordering, i.e., procurement. In Table 2 is explained in detail the importance of factors for creating partnerships according to the responses of procurement employees. 
Table 2. The importance of factors for creating partnerships in the procurement sector

\begin{tabular}{|c|c|c|c|c|c|c|c|c|c|c|c|c|}
\hline & \pm & 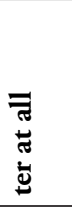 & 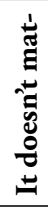 & $\begin{array}{l}0 \\
0 \\
0 \\
0 \\
0 \\
0 \\
0 \\
0 \\
0 \\
0\end{array}$ & 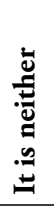 & 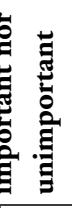 & 跣 & 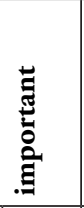 & & 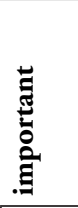 & $M$ & $S D$ \\
\hline & $\mathbf{f}$ & $\%$ & f & $\%$ & $f$ & $\%$ & $\mathbf{f}$ & $\%$ & f & $\%$ & & \\
\hline Regular communication & 0 & 0 & 0 & 0 & 1 & 2,1 & 7 & 14,6 & 40 & 83,3 & 4,81 & 0,445 \\
\hline $\begin{array}{l}\text { Professional approach to } \\
\text { communication }\end{array}$ & 0 & 0 & 1 & 2,1 & 3 & 6,3 & 13 & 27,1 & 31 & 64,6 & 4,54 & 0,713 \\
\hline $\begin{array}{l}\text { Holding regular meet- } \\
\text { ings }\end{array}$ & 0 & 0 & 1 & 2,1 & 10 & 20,8 & 16 & 33,3 & 21 & 43,8 & 4,19 & 0,842 \\
\hline $\begin{array}{l}\text { As low as possible prices } \\
\text { of the offered products } \\
\text { / services }\end{array}$ & 0 & 0 & 4 & 8,3 & 9 & 18,8 & 18 & 37,5 & 17 & 35,4 & 4 & 0,945 \\
\hline $\begin{array}{l}\text { Timely response to a } \\
\text { complaint }\end{array}$ & 0 & 0 & 1 & 2,1 & 1 & 2,1 & 8 & 16,7 & 38 & 79,2 & 4,73 & 0,61 \\
\hline $\begin{array}{l}\text { Shortening the delivery } \\
\text { time in emergency situ- } \\
\text { ations }\end{array}$ & 0 & 0 & 0 & 0 & 1 & 2,1 & 15 & 31,3 & 32 & 66,7 & 4,65 & 0,526 \\
\hline $\begin{array}{l}\text { Currency of payment } \\
\text { (advance payment, } \\
\text { deferred payment) }\end{array}$ & 0 & 0 & 5 & 10,4 & 11 & 22,9 & 11 & 22,9 & 21 & 43,8 & 4 & 1,052 \\
\hline $\begin{array}{l}\text { Quality logistical sup- } \\
\text { port during delivery }\end{array}$ & 0 & 0 & 1 & 2,1 & 3 & 6,3 & 15 & 31,3 & 29 & 60,4 & 4,5 & 0,715 \\
\hline $\begin{array}{l}\text { Gifts and attention } \\
\text { signs for holidays / } \\
\text { birthdays }\end{array}$ & 14 & 29,2 & 14 & 29,2 & 9 & 18,8 & 7 & 14,6 & 4 & 8,3 & 2,44 & 1,287 \\
\hline $\begin{array}{l}\text { Quick replies to } \\
\text { emails }\end{array}$ & 0 & 0 & 0 & 0 & 4 & 8,3 & 15 & 31,3 & 29 & 60,4 & 4,52 & 0,652 \\
\hline $\begin{array}{l}\text { Free help / advice } \\
\text { on product / service } \\
\text { development }\end{array}$ & 2 & 4,2 & 0 & 0 & 9 & 18,8 & 17 & 35,4 & 20 & 41,7 & 4,1 & 0,994 \\
\hline $\begin{array}{l}\text { Constant reminder of } \\
\text { expanding collabora- } \\
\text { tion and new orders }\end{array}$ & 3 & 6,3 & 7 & 14,6 & 16 & 33,3 & 7 & 14,6 & 15 & 31,3 & 3,5 & 1,255 \\
\hline $\begin{array}{l}\text { Pointing out the } \\
\text { negative sides of com- } \\
\text { peting companies }\end{array}$ & 14 & 29,2 & 14 & 29,2 & 10 & 20,8 & 5 & 10,4 & 5 & 10,4 & 2,44 & 1,303 \\
\hline
\end{tabular}

Source: authors. 
Employees in the procurement sector as the most important factors assess regular communications $(M=4.81)$, timely responses to complaints $(M=4.73)$, shortening the delivery time in emergency situations $(M=65)$, quick responses to e-mails $(\mathrm{M}=4.52)$ and the quality logistical support during deliveries $(\mathrm{M}=$ 4.50). It is not necessarily a matter of crisis communication, but regular communication of day-to-day business can build strong and stable partnerships that can last for a long period of time. Procurement representatives and supplier representatives (often two individuals) directly influence on the turnover between the two companies, building relationships, the way of resolving complaints, but also the partnership resolution of crisis situations. Respondents of the procurement business confirmed that regular communication is the most important and thus influenced on the confirmation of hypothesis H1. They consider gifts and signs of attention for holidays / birthdays and also pointing out the negative sides of competing companies, both as the least important factors $(M=2.44)$. Both statements are marked as equally unimportant in creating partnerships. Pointing out to the negative sides of competing companies is not only undesirable, but it's also not professional to negatively comment on other businesses without evidence and based only on insinuations. Procurement employees may get the impression that a supplier who negatively comments on a competition through manipulative data wants to reject a competitor. The ethics of such a way of communicating is highly questionable. Gifts and signs of attention should never be important, and at least crucial factors for creating a great partnership. There are numerous examples where expensive gifts are characterized as decisive factors for the selection of suppliers, which are by no means non-ethical, and in particular are not lawful actions in state-owned companies. Selection of procurement suppliers should work according to the well-established commercial criteria and quality criteria, and everything else would raise doubts about the ethics of such business. To the respondents were offered claims related to the supplier assistance in times of crisis, and which answers were selected by procurement staff are shown in Figure 3. 
Figure 3. Supplier assistance during times of crisis

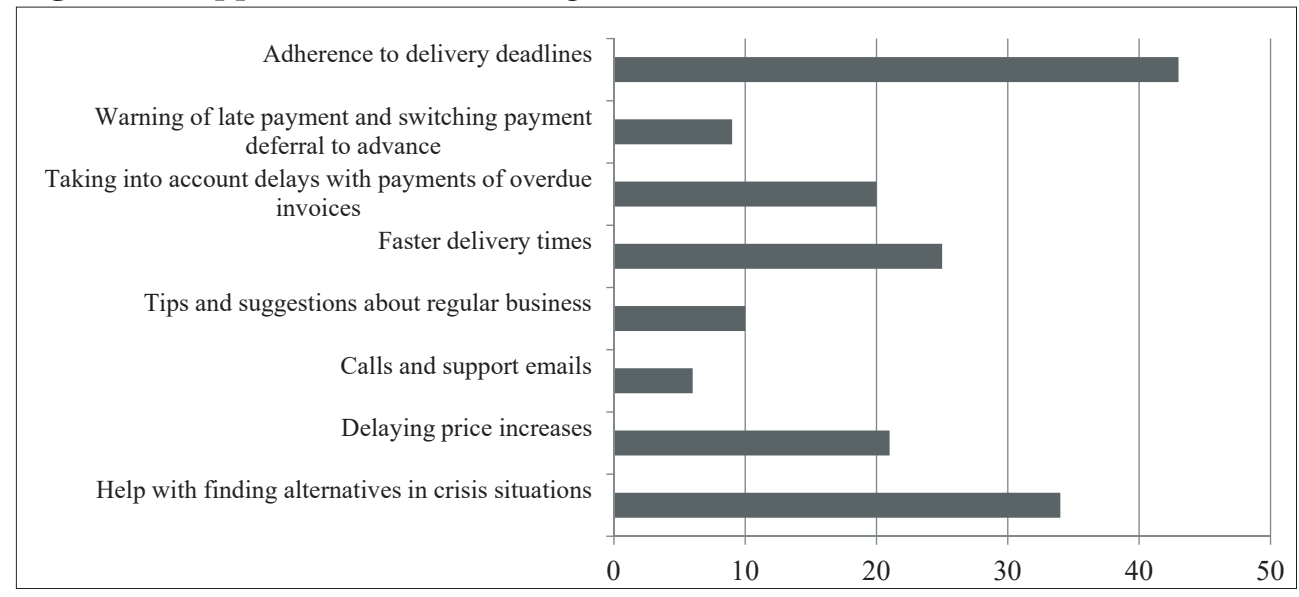

Source: authors.

Participants cite compliance with delivery deadlines and assistance in finding alternatives in crisis situations as the best ways for giving help to the suppliers during the course of crisis. The task of procurement in normal market conditions is to provide the required goods and services for uninterrupted business and business development. This task is especially pronounced during market instability, regardless of whether it was because of an increase in prices, a shortage of raw materials, war or pandemics. When creating a need for a particular good or service by production, sale or procurement itself, the estimated delivery time set by the selected supplier is taken into account at the outset. The production plan is based on the sales plan, and in the case of consumer goods, the logistical conditions and exact delivery dates to customers have certainly already been agreed. If the company's business is organized in this way, procurement has an easier job in crisis situations, because at least it has available information's related to the production needs for inputs or services. On the Figure 4 is shown which factors, according to the respondents' answers, had the greatest impact on business difficulties at the beginning of the COVID-19 pandemic. 
Figure 4. Factors that caused the most problems at the onset of the Covid-19 pandemic

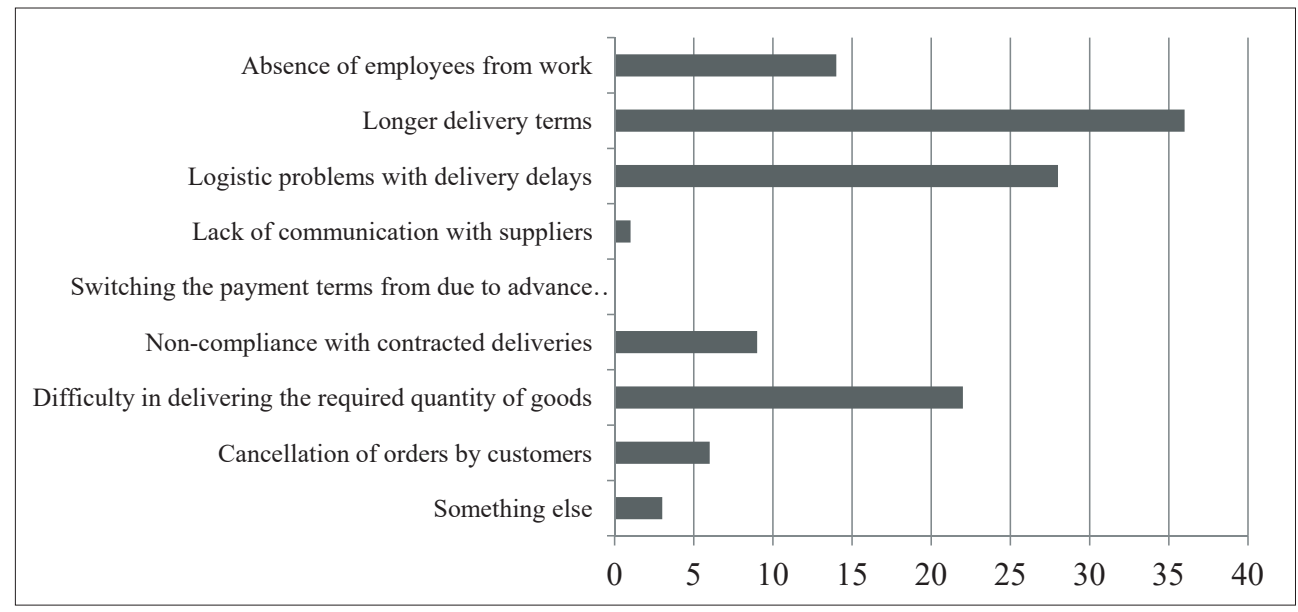

Source: authors.

Most of the problems at the beginning of the Covid-19 pandemic were caused by longer delivery times of suppliers, logistical problems with delivery delays and the inability to deliver the requested goods. The absence of employees during that period was not a key problem, as the pandemic still did not affect a large number of people as it did a year later. There was a crisis and market disturbance, initially even the borders between the Republic of Croatia and neighbouring countries were closed. After a few days of tension, the traffic of goods across the border was regulated, but the drivers were still under great pressure. For all of the above said resulted in delays in deliveries, the inability to find carriers and, in general, the inability to deliver goods. In Table 3 are shown the results of a survey of procurement staff related to activities to better prepare for the future crisis periods. 
Table 3. Importance of activities for better preparation for the future crisis periods

\begin{tabular}{|c|c|c|c|c|c|c|c|c|c|c|c|c|}
\hline & \multicolumn{2}{|c|}{$\begin{array}{c}\text { It } \\
\text { doesn't } \\
\text { matter } \\
\text { at all }\end{array}$} & \multicolumn{2}{|c|}{$\begin{array}{c}\text { It } \\
\text { doesn't } \\
\text { matter } \\
\text { to some } \\
\text { extent }\end{array}$} & \multicolumn{2}{|c|}{\begin{tabular}{|c|} 
It is \\
neither \\
impor- \\
tant nor \\
unim- \\
portant
\end{tabular}} & \multicolumn{2}{|c|}{$\begin{array}{c}\text { It's } \\
\text { some- } \\
\text { what } \\
\text { impor- } \\
\text { tant }\end{array}$} & \multicolumn{2}{|c|}{$\begin{array}{l}\text { It is ex- } \\
\text { tremely } \\
\text { impor- } \\
\text { tant }\end{array}$} & \multirow[t]{2}{*}{$M$} & \multirow[t]{2}{*}{$S D$} \\
\hline & $f$ & $\%$ & $\mathrm{f}$ & $\%$ & $\mathrm{f}$ & $\%$ & $\mathrm{f}$ & $\%$ & $\mathrm{f}$ & $\%$ & & \\
\hline $\begin{array}{l}\text { Better enterprise inventory } \\
\text { planning }\end{array}$ & 0 & 0 & 0 & 0 & 2 & 4,2 & 8 & 16,7 & 38 & 79,2 & 4,75 & 0,526 \\
\hline $\begin{array}{l}\text { Adding an annex to the con- } \\
\text { tract by which behaviour in } \\
\text { times of crisis is defined }\end{array}$ & 3 & 6,3 & 7 & 14,6 & 13 & 27,1 & 17 & 35,4 & 8 & 16,7 & 3,42 & 1,127 \\
\hline $\begin{array}{l}\text { Creating additional financial } \\
\text { stocks / better cash flow con- } \\
\text { trol }\end{array}$ & 0 & 0 & 0 & 0 & 6 & 12,5 & 18 & 37,5 & 24 & 50 & 4,38 & 0,703 \\
\hline $\begin{array}{l}\text { Internal training on crisis } \\
\text { management }\end{array}$ & 0 & 0 & 5 & 10,4 & 9 & 18,8 & 18 & 37,5 & 16 & 33,3 & 3,94 & 0,976 \\
\hline $\begin{array}{l}\text { Internal training on crisis } \\
\text { communication }\end{array}$ & 0 & 0 & 3 & 6,3 & 11 & 22,9 & 19 & 39,6 & 15 & 31,3 & 3,96 & 0,898 \\
\hline $\begin{array}{l}\text { Creating a list of trusted sup- } \\
\text { pliers / partners }\end{array}$ & 2 & 4,2 & 7 & 14,6 & 7 & 14,6 & 16 & 33,3 & 16 & 33,3 & 3,77 & 1,189 \\
\hline $\begin{array}{l}\text { Team building activities in the } \\
\text { company }\end{array}$ & 3 & 6,3 & 8 & 16,7 & 12 & 25 & 12 & 25 & 13 & 27,1 & 3,5 & 1,238 \\
\hline $\begin{array}{l}\text { Investing time and effort in } \\
\text { improving partnerships }\end{array}$ & 0 & 0 & 1 & 2,1 & 4 & 8,3 & 17 & 35,4 & 26 & 54,2 & 4,42 & 0,739 \\
\hline $\begin{array}{l}\text { Creating a crisis strategy for all } \\
\text { sectors }\end{array}$ & 0 & 0 & 1 & 2,1 & 4 & 8,3 & 15 & 31,3 & 28 & 58,3 & 4,46 & 0,743 \\
\hline
\end{tabular}

Source: authors.

Employees in the procurement sector state that the most important activities for better preparation for the future periods of crisis are better inventory planning of companies $(M=4.75)$, creating a crisis strategy for all sectors $(M=4.46)$, investing time and effort in improving partnerships $(M=4.42)$, and creation of additional financial stocks / better cash flow control $(M=4.38)$. Safety stocks primarily depend on the company's storage capacity, but a certain minimum stock must always be set for the key materials. The instability of deliveries during the first lockdown caused by the COVID-19 pandemic lasted a little less than a month, so companies that could and wanted to organize a one-month minimum stock of key materials survived the period without much turbulence. Crisis strategies do not have to be extremely detailed, but they must be arranged through well-developed procedures so that all sectors know how to behave in future crises. It is extremely risky to 
create crisis procedures when the crisis has already started, because it can lead to even greater confusion and panic among the employees. Partnerships in any crisis prove to be crucial, because all partners are interconnected, regardless of whether they are in the role of a customer, supplier, intermediary, third party, etc. There will always be partners who will not act as partners in times of crisis, but will turn to protection their own business regardless of cost. All crises result in financial consequences, due to lack of demand, difficulties with production, delayed input or absence of employees. Through careful planning and stockpiling, company can create financial security that will always be one of the key factors.

\section{CONCLUSION}

Crisis and unpredictable situations that can negatively affect a company's business will always be a threatening danger. Welfare conditions can deceive employees and managers and can create false self-confidence that leads to insufficiently decisive and effective strategic and operational measures at the beginning of the crisis situations. Purchasing operations in all market situations have an extremely key function for achieving stability and growth, especially during crisis conditions. This research was conducted among employees of the procurement business from the territory of the Republic of Croatia. The research comprehended questions related to examining the factors that are important for creating and maintaining partnerships, how suppliers can help during times of crisis, the factors that most affected business difficulties at the beginning of the Covid-19 virus pandemic and also what activities of purchasing operations should be implemented to better prepare for the future crisis periods. The research has shown that for creating partnerships, the most important are regular communication, timely responses to complaints and shortening delivery times in emergency situations. Purchasing business has its own specific requirements towards partners, but the important conclusion is that among the most important factors we consider regular communication. Procurement employees responded that the most important activities of suppliers in times of crisis are compliance with delivery deadlines, faster (shorter) delivery deadlines and finding alternatives in crisis situations. The deadlines for the delivery of ordered goods and services directly affect the production in the final result of the business, so it is not surprising to see that the above statement received the most confirmation from the procurement staff. These statements have confirmed the hypothesis $\mathrm{H} 2$ - to the procurement employees in crisis situations are more important delivery times, quality cooperation and assistance from suppliers in finding alternative solutions than the lowest price and payment terms. Partners will always help each other when finding alternatives in any aspect of the business, especially if the situation is extremely urgent and threatens to stop production. The 
COVID-19 virus pandemic has caused a number of turbulences and instabilities around the world, and it was especially challenging and unpredictable during the spring of 2020. Procurement employees were most challenged during this period by longer delivery times, logistical problems with the delayed deliveries, absence of employees from work and inability to deliver the requested goods. The three biggest factors are directly related to the supplier and the logistics part of the business. Longer delivery times were expected due to the announced restrictions on population movements and numerous measures that were announced, but the biggest challenge for planning of the procurement was the sudden restrictions for lorry drivers when crossing the border and entering other countries. The most difficult situation was at the beginning of April 2020, when the entire traffic between the Republic of Croatia and neighbouring countries was closed for a few days, but a few days later the decision was made that all drivers that were entering the country must be in a two-week quarantine. The price of transportation jumped sharply and it was almost impossible to find a vehicle to make the delivery. The situation was quickly regulated and transport traffic was returned to a certain normal, but with certain restrictions. From each crisis it is important to draw conclusions and adjust business to the new situations. Respondents from the procurement business answered that the most important measures for preparation for future crisis periods are better planning of companies' stocks of materials, creating a crisis strategy for all sectors and investing time and effort in improving partnerships. These results have fully confirmed the $\mathrm{H} 1$ and $\mathrm{H} 3$ hypothesis, i.e., (H1) investing time in the activity of creating and maintaining partnerships is crucial in unpredictable crisis situations in the market, and (H3) awareness of the importance of internal training on crisis management, and the importance of team building activities is highly present at the procurement employees.

When comparing this paper with other papers, some of the papers dealt with the business crisis of the whole company, not for just one isolated function. A small number of authors have dealt rigorously with crisis analysis within procurement. Analysed research has confirmed that active companies, which carry out activities to anticipate and eliminate business risks, better cope with crisis situations. In addition to the abovementioned, it turned out that many managers simply do not have enough experience in the environment or business history in the market in which they operate to offer adequate strategies to handle the crisis situations. Managers of smaller companies do not have enough experience, while managers of large companies do not have enough financial resources for preventive activities. The common conclusion between the observed research and this paper is the realization that managers are aware of the need to develop processes and strategies within the company to overcome crisis situations. The contribution of 
science work is an overview of the opinions of procurement employees regarding to the development of partnerships and what are the expectations towards partners in crisis situations. Precisely presented are the activities that have the greatest impact on the development of partnerships and what is important to the procurement employees. Another contribution of science would be research related to the challenges of the procurement business during the COVID-19 pandemic, where it was shown exactly what were the biggest problems of the procurement business and what activities should be applied to help overcome future crises. There are very few papers that directly analyse the procurement business to so many specific processes and situations. Future research can offer answers to questions about which business strategies and processes within the company are most effective for crisis prevention with the least invested financial resources, and in terms of procurement operations, which specific activities would help procurement given the activity and size of the company to adapt everyday processes to future crises situations.

\section{REFERENCES}

\section{BOOKS AND ARTICLES}

1. Biondić Vince, D., Kako uspješno pregovarati i povećati svoju vrijednost, napredovati, te zaraditi više!, vodič za vrhunske pregovarače, Biondi, Zagreb, 2012

2. Brčić, R.; Malbašić, I.; Đukes, S., Uloga i ponašanje zaposlenika u kriznom menadžmentu, Ekonomski pregled, Vol. 64, No. 3, 2013, pp. 279-296

3. Filipović, D.; Krišto, M.; Podrug, N., Impact of crisis situations on development of business continuity management in Croatia, Management : Journal of Contemporary Management Issues, Vol. 23, No. 1, 2018, pp. 99-122

4. Funda, D., Doprinos mectunarodnih norma u rješavanju poslovnih kriza, Visoka škola za poslovanje i upravljanje s pravom javnosti «Baltazar Adam Krčelić» Zaprešić, Hrvatska, Tranzicija, Vol. 13, No. 27, 2011, pp. 98-109

5. Grawe, S.J.; Ralston, P.M., Intra-organizational communication, understanding, and process diffusion in logistics service providers, International Journal of Physical Distribution \& Logistics Management, Vol., No. 6, 2019, pp. 662-678

6. Jugo, D., Menadžment kriznog komuniciranja, Školska knjiga, Zagreb, 2017

7. Keränen, O., Dynamics of the transition process towards partnership thinking in centralized public procurement, Industrial Marketing Management, Vol. 65, 2017, p. 86-99

8. Kruljac, Ž.; Knežević, D., Prevencija ili evidencija: prepoznati rane simptome krize ili evidentirati gubitke u poslovanju?, Obrazovanje za poduzetništvo - E4E : znanstveno stručni časopis o obrazovanju za poduzetništvo, Vol. 10, No. 2, 2020, pp. 155-168

9. Leinert-Novosel, S., Komunikacijski kompas, Plejada, Zagreb, 2012 
10. Lujanac, D.; Mihalinčić, M.; Markotić, I.; Kožul, I., Krizni menadžment zdravstva, Journal of Applied Health Sciences $=$ Časopis za primijenjene zdravstvene znanosti, Vol. 4, No. 1, 2018, pp. 115-120

11. McIvor, R.; McHugh, M., Partnership sourcing: an organization change management perspective, Journal of Supply Chain Management, Vol. 36, No. 2, 2000, p. 12-20

12. Mikušová, M.; Horváthová, P., Prepared for a crisis? Basic elements of crisis management in an Organisation, Economic research - Ekonomska istraživanja, Vol. 32, No. 1, 2019, pp. 1844-1868

13. Mohr, J.; Spekman, R., Characteristics of partnership success: partnership attributes, communication behavior, and conflict resolution techniques, Strategic management journal, Vol. 15, No. 2, 1994, p. 135-152

14. Novak, B., Krizno komuniciranje i upravljanje opasnostima : priručnik za krizne odnose s javnošcu, Binoza press Zagreb, 2001,

15. Petar, S., Sastankom do cilja : vještina vodenja uspješnih sastanaka, Školska knjiga, Zagreb, 2013

16. Rouse, M.; Rouse, S., Poslovne komunikacije : kulturološki i strateški pristup, Zagreb, 2005

17. Sodhi, M. S.; Son, B. G., Supply-chain partnership performance, Transportation Research Part E: Logistics and Transportation Review, Vol. 45, No. 6, 2009, p. 937-945

18. Tafra-Vlahović, M., Upravljanje krizom : procjene, planovi, komunikacija, Visoka škola za poslovanje i upravljanje s pravom javnosti "Baltazar Adam Krčelić", Zaprešić, 2011

19. Tomašević Lišanin, M., Profesionalna prodaja i pregovaranje, Hrvatska udruga profesionalaca u prodaji, Zagreb, 2010

20. Tomić, Z.; Sapunar, J., Krizno komuniciranje, časopis Filozofskog fakulteta Sveučilišta u Mostaru, No. 1, 2006, pp. 298-310

21. Vodopija, Š., Opća i poslovna komunikacija: priručnik i savjetnik za uspješnu komunikaciju, Naklada Žagar, Rijeka, 2006 